\title{
ЗНАЧЕННЯ НАУКОВИХ ДОСЛІДЖЕНЬ ДЛЯ ВИЗНАЧЕННЯ ТА ВИРІШЕННЯ ОСНОВНИХ ПРОБЛЕМ В МЕДСЕСТРИНСТВІ
}

\author{
Значення наукових досліджень для визначення та \\ вирішення основних проблем в медсестринстві \\ С. О. Ястремська ${ }^{1}$, О. М. Намісняк ${ }^{1}$, Г. Б. Гуменюк ${ }^{2}$ \\ Тернопільський національний медичний університет \\ імені І. Я. Горбачевського МОЗ України ${ }^{1}$ \\ Тернопільський національний педагогічний \\ університет імені Володимира Гнатюка²
}

Резюме. У світі за останні кілька десятиліть культура медсестринства зазнала глибоких змін. Від медичних сестер все більше очікується, що вони розуміють $i$ проводять дослідження, а також базують свою профресійну практику на доказах, що з'являються в результаті досліджень, тобто застосовують доказове медсестринство. Доказове медсестринство широко визначається як використання найкращих клінічних даних при прийнятті рішень щодо догляду за пацієнтами, і такі докази зазвичай надходять із досліджень, проведених медсестрами та іншими фрахівцями охорони здоров'я. У деяких дослідженнях показано взаємозв'язок між дослідженнями, доказовою практикою у медсестринстві, а також підвищення якості медсестринського догляду.

Мета дослідження - проаналізувати літературні джерела останнього десятиліття щодо результативності та доцільності медсестринських наукових досліджень на якість здоров'я населення, а також показати значення наукових досліджень для визначення та вирішення основних проблем у вітчизняному медсестринстві.

Матеріали і методи. Проведено аналіз доступних інсрормаційних ресурсів у мережі «Інтернет», іноземних фрахових видань за останні десять років. Застосовано аналітико-порівняльний метод та метод інсрормаційного пошуку.

Результати. За останні кілька десятиліть культура медсестринства зазнала глибоких змін. Наукові відкриття, що впливають на розуміння здоров'я, хвороб, включаючи симптоми, а також нові методи діагностики та лікування, продовжують розвиватися. На часі $\epsilon$ зміни в практиці, дослідженнях та освіті медичних сестер. На практиці інноваційні, спільно створені, засновані на доказах моделі надання допомоги можуть відкрити нові ролі для медичних сестер з вищою освітою, які мають знання, лідерські та командні навички та вміння наукового пошуку й проведення досліджень. Дані наукових медсестринських досліджень можуть стати основою
The value of scientific research in identifying and solving nursing problems

S. O. Yastremska ${ }^{1}$, O. M. Namisnyak ${ }^{1}$, G. B. Gumenyuk ${ }^{2}$

I. Horbachevsky Ternopil National Medical University ${ }^{1}$ Ternopil Volodymyr Hnatiuk National Pedagogical University ${ }^{2}$

e-mail: yastremska@tdmu.edu.ua

Summary. Around the last few decades, nursing culture has seen significant changes all over the world. Nurses are increasingly required to comprehend and perform research, as well as to base their professional practice on research results, or to practice evidence-based nursing. Evidencebased nursing is described as the use of the most up-todate clinical data in making patient-care choices, and such data is typically derived from nurse and other health-care professional research. Some studies [1, 2] have found a correlation between nursing research, evidence-based practice, and improved nursing care quality.

The aim of the study - to examine recent literature on the effectiveness and feasibility of nursing research on public health quality, as well as to demonstrate the value of research in identifying and solving important nursing problems in Ukraine.

Materials and Methods. For the previous 10 years, an examination of available information resources on the Internet and international professional periodicals has been conducted. The methods of analytical-comparative analysis and information search are used.

Results. The nursing profession's culture has shifted considerably during the last few decades. Scientific advances that influence our understanding of health, disease, and symptoms, as well as novel diagnostic and therapeutic procedures, continue be in progress. Nurses' practice, research, and education are all changing. In reality, creative, collaborative, evidence-based care models can create new opportunities for higher educated nurses with knowledge, leadership and team-building skills, as well as ability to do study and research. To illustrate the value of nursing care, nursing research data can provide a foundation for clinical practice and improve the knowledge base of nurses in science on symptoms, health, self-management, and end-of-life palliative care, as well as behavioral health. Personalized, integrative, and technology teaching and learning can help students develop creative and critical thinking abilities, ethical 
для клінічної практики та розширити базу знань медичних сестер у науці щодо симптомів, здоров'я, самоконтролю та паліативної допомоги наприкінці життя, а макож поведінкового здоров'я, щоб продемонструвати цінність медсестринського догляду. В освіті персоналізоване, інтегративне та технологічне викладання та навчання може призвести до творчого та критичного мислення/прийняття рішень, етичних та культурно інклюзивних основ для практики здобувачів з медсестринства, забезпечити командні та комунікативні навички, покращити якість навчання протягом усього життя.

Висновки. У сучасному світі медичні сестри повинні навчатися протягом усього життя, бути здатними обмірковувати, оцінювати та модифікувати свою клінічну практику на основі знань, отриманих від систематичних досліджень у сорері медсестринства та охорони здоров'я. Знання, які можуть надати майбутні вчені-медсестри, будуть вирішальними для посилення зміцнення здоров'я, боротьби з хронічними, інфекційними та психічними захворюваннями, а також для сприяння одужанню та покращення якості життя

Ключові слова: сестринська справа; доказова практика; підвищення якості; освіта; дослідницька мережа.

\section{ВСТУП}

Упродовж XXI ст. роль медичної сестри значно змінилася. Медсестри працюють у різних умовах, включаючи роботу в різноманітних державних і приватних лікувальних закладах, навчають студентів, ведуть приватну медсестринську діяльність, забезпечують медсестринську допомогу вдома та роботу в лабораторіях. Хоча кожна роль несе різні обов'язки, основна мета професійної медсестри залишається незмінною: бути захисником пацієнта та надавати оптимальний догляд на основі доказів, отриманих в результаті досліджень $[5,6]$. Щоб досягти цієї мети, медсестрам постійно потрібно отримувати доступ до нової інформації й оцінювати та включати її у свої клінічні рішення. У сучасному світі медичні сестри повинні навчатися протягом усього життя, бути здатними обмірковувати, оцінювати та модифрікувати свою клінічну практику на основі знань, отриманих від систематичних досліджень у сорері медсестринства та охорони здоров'я.

У світі за останні кілька десятиліть культура медсестринства зазнала глибоких змін. Від медичних сестер все більше очікується, що вони розуміють і проводять дослідження, а також базують свою профресійну практику на доказах, що з'являються в результаті досліджень, тобто застосовують доказове медсестринство [7]. Доказове медсестринство широко визначається як використання найкращих клінічних даних при прийнятті рішень щодо догляду за пацієнтами, і такі докази зазвичай надходять із досліджень, проведених медсестрами та іншими орахівцями охорони здоров'я [1, 2]. and culturally inclusive foundations for nursing practice, teamwork and communication skills, and improve the quality of lifelong learning.

Concusions. Nurses in today's society must continue to study throughout their careers in order to be able to reflect on, analyze, and adapt their clinical practice based on the findings of systematic nursing and health-care research. Future nurse scientists' knowledge will be crucial in improving health promotion, addressing chronic and infectious diseases, and mental illness, as well as aiding recovery, and improving quality of life.

Key words: nursing; evidence-based practice; quality improvement; education; research network.

Метою дослідження було проаналізувати літературні джерела останнього десятиліття щодо результативності та доцільності медсестринських наукових досліджень на якість здоров'я населення, а також показати значення наукових досліджень для визначення та вирішення основних проблем у вітчизняному медсестринстві.

\section{МАТЕРІАЛИ I МЕТОДИ}

Проведено аналіз доступних інфрормаційних ресурсів у мережі «Інтернет», іноземних фрахових видань за останні десять років. Застосовано аналітико-порівняльний метод та метод інформаційного пошуку.

\section{РЕЗУЛЬТАТИ Й ОБГОВОРЕННЯ}

Сьогодні медсестри визнають необхідність базувати конкретні медсестринські дії та рішення на доказах, які вказують на те, що ці дії є клінічно доцільними, економічно ефективними та призводять до позитивних результатів для пацієнтів.

У Сполучених Штатах дослідження стали відігравати важливу роль у медсестринській справі 3 точки зору акредитації та статусу. Американський центр сертисрікації медсестер - підрозділ Американської асоціації медичних сестер - розробив програму Magnet Recognition Program ${ }^{\circledR}$ для визнання організацій охорони здоров'я, які надають високоякісний медичний догляд, а також для підвищення стандартів та репутації профресії медсестри [8].

У свій час більшість медсестер-дослідників були вченими, які викладали в школах медсестер, але на сьогодні дослідження все частіше проводять прак- 
тичні медсестри, які хочуть знайти те, що найкраще підходить для їхніх пацієнтів [9, 10]. У зв'язку з нинішнім акцентом на доказові дослідження, обов'язком кожної медичної сестри стало виконувати одну або кілька ролей у безперервному дослідженні. Так, на одному кінці континууму знаходяться користувачі (споживачі) медсестринських досліджень - медсестри, які читають звіти про дослідження, щоб розвивати нові навички та бути в курсі відповідних висновків, які можуть вплинути на їхню практику. На іншому кінці континууму знаходяться виробники медсестринських досліджень - медсестри, які активно беруть участь у розробці та проведенні досліджень. Між цими двома кінцевими точками континууму споживач-виробник лежать різноманітні дослідницькі заходи, в яких можуть брати участь медсестри. Навіть якщо медична сестра самостійно не проводить наукове дослідження, вона може бути його учасником і виконувати одне або кілька з наступного:

- брати участь у зустрічах медсестринського колективу на робочому місці для обговорення та критики дослідницьких статей з медсестринства;

- брати участь у професійних коноеренціях;

- вирішувати клінічні проблеми та приймати клінічні рішення на основі проведених ретельних досліджень;

- допомогти розробити ідею клінічного дослідження;

- проаналізувати запропонований план дослідження та надати свої пропозиції для покращення цього плану;

- допомагати дослідникам, залучаючи потенційних учасників дослідження або збираючи інформацію про дослідження (наприклад розповсюджуючи анкети пацієнтам);

- надавати інорормацію та консультації пацієнтам щодо участі в дослідженнях;

- обговорювати 3 пацієнтами наслідки та актуальність результатів дослідження.

У всіх можливих видах діяльності, пов'язаних із дослідженнями, медсестри, які мають певні дослідницькі навички, можуть краще, ніж ті, хто їх не має, зробити внесок у доказове медсестринство [11].

Поступово медична реформа в Україні підвищує запити на спеціалістів із вищою освітою 3 медсестринства: бакалаврів, магістрів та докторів фрілософії, але медсестра в Україні й у світі - поки що це дві великі різниці. Медсестри з вищою освітою в Україні з'явилися не так давно як у світі $[12,13]$. У розвинутих країнах світу таких фрахівців почали готувати ще на початку минулого століття. Піонер у цьому питанні - США, де у 1932 р. перша медсестра-магістр захистила науковий ступінь «Доктор фрілософії 3 медсестринства». Починаючи 3 80-х років минулого століття країни Європи також готують медсестер за освітніми ступенями «Бакалавр», «Магістр» та «Доктор фрілософрії».
В Україні, на жаль, багато хто вважає, що сьогодні існує просто мода на вищу освіту, а медсестра - вона в будь-якій іпостасі просто медсестра. Хоча зрозумілою для всіх є аксіома: молодший спеціаліст, бакалавр, магістр і доктор фрілософії - це різні освітні ступені й мають зовсім іншу підготовку [13]. Частими є також хибні уявлення про те, що таке дослідження медсестер і чи можуть взагалі медсестри проводити свої власні наукові дослідження. Деякі люди навіть не знають, як дати визначення медсестринським дослідженням. Згідно з тлумаченням американських науковців, дослідження медсестер - це систематичне дослідження, призначене для розвитку знань із питань, важливих для медсестер, у тому числі медсестринської практики, медсестринської освіти та адміністрування медсестринської справи [11].

Медсестринські дослідження є життєвоважливими для практики професійного медсестринства, i науковці по всьому світу, а тепер і в Україні усвідомлюють, що догляд і дослідження можна поєднувати і що оптимальний догляд залежить від останніх результатів досліджень. Крім того, дослідникимедсестри є цінними для практичних медсестер. Інорормація, отримана медсестрою-науковцем, може бути поширена серед медсестер, які працюють безпосередньо з особами, яких стосується це дослідження [6, 9, 10].

Програми бакалаврату, магістратури та аспірантури з медсестринства навчають медсестер оцінювати та використовувати дослідження у своїй повсякденній кар'єрі, порівнювати результати та читати опубліковані дослідження, тобто навчають інсрормаційній грамотності.

Хоча більшість медсестер, яка здійснює догляд за пацієнтами, будуть споживачами медсестринських досліджень, впровадження медичної практики, заснованої на доказах, має вирішальне значення для забезпечення оптимального медсестринського догляду.

Медсестринські дослідження - це сфера, що розвивається, в якій науковці можуть застосувати свою медсестринську освіту для відкриття нових досягнень, що сприяють догляду, заснованому на доказах [2].

Дослідження допомагають медсестрам визначити ефективні передові методи та покращити догляд за пацієнтами. Медсестри-науковці вчаться отримувати, читати, критикувати та застосовувати вже наявні дослідження в медсестринстві та розуміти важливість цих досліджень. Дослідження також допомагають медсестринству реагувати на зміни в середовищі охорони здоров'я, популяції пацієнтів та урядових постановах. Оскільки дослідники роблять відкриття, практика медсестринства продовжує змінюватися. Сучасні наукові дослідження в медсестринстві, їх результати використовуються і
Вісник медичних і біологічних досліджень Bulletin of Medical and Biological Research
$4(10), 2021$ 
викладачами у вищих навчальних закладах при додипломній та післядипломній програмах підготовки майбутніх медичних сестер [1].

Кожна медсестра може отримати користь від того, щоб знати, чому дослідження медсестер важливі, як проводяться дослідження та як дослідження інорормують про лікування пацієнтів.

Програми бакалаврату, магістратури та аспірантури з медсестринства навчають медсестер оцінювати та використовувати дослідження у своїй повсякденній кар'єрі, порівнювати результати та читати опубліковані дослідження, тобто навчають інфрормаційній грамотності.

Інорормаційна грамотність та медсестринство

Інформаційна грамотність - це не те саме, що вміння читати, ефективно користуватися комп'ютером чи користуватися пошуковими системами. Ця навичка виходить за рамки розуміння основ пошуку ресурсів. Розуміння інсрормації перетворює її з знань, які вже є у науковця, у знання, які можна реально використовувати. Медсестри, які навчаються ефективно обробляти та використовувати інфрормацію з опублікованих досліджень, можуть покращити свою інфрормаційну грамотність, тому що просте читання результатів дослідження мало допоможе, якщо не розуміти прочитаного [2]. В навчальний план аспірантури з медсестринства Тернопільського національного медичного університету введені ряд навчальних дисциплін, які фрормують в майбутніх науковців з медсестринства такі компетентності як вміння інтерпретувати дані, порівнювати різні дослідження, обробляти інформацію, критикувати результати та критично мислити. Інфрормаційна грамотність дає можливість медсестрам використовувати дослідження у своїй кар'єрі, щоб вони могли приймати важливі клінічні рішення.

Викладання інфрормаційної грамотності

Навчальні програми з підготовки бакалаврів, магістрів та докторів фрілософії з медсестринства передбачають фрормування у здобувачів такої компетенції як потреба звернення до досліджень у відповідь на проблеми та запити суспільства. 3 цією метою багато закладів вищої медичної освіти, де готують медичних сестер співпрацюють з бібліотекарями-дослідниками, щоб допомогти здобувачам стати більш компетентними у використанні інорормації. Проблемне навчання дозволяє здобувачам використовувати доступні інформаційні ресурси, коли вони стикаються 3 клінічними проблемами. Практика цих навичок в академічному середовищі готує медичних сестер до використання інорормаційних ресурсів у власній клінічній практиці [10].

Практика, заснована на доказах

Практика, заснована на доказах, вимагає використання результатів досліджень для прийняття клінічних рішень та надання допомоги. Медичні сестри повинні базувати свою роботу на результатах досліджень. Опубліковані дані, що рецензуються, і які в цілому приймаються в медсестринстві, служать керівництвом і встановлюють передовий досвід у цій галузі [11]. Дотримання доказів, куди б вони не вели, є ключем до практики, заснованої на принципах доказовості. У XXI ст. одним із способів, у якому медсестринська справа покладається на доказову практику для покращення результатів і догляду за пацієнтами, є використання рекомендацій з найкращої практики. У світі ряд медсестринських організацій взяли на себе ініціативу і створили різні рекомендації щодо найкращої практики, щоб дипломовані медичні сестри з більшою готовністю використовувати принципи доказовосты при прийнятті рішень щодо догляду за пацієнтами. Так у Канаді Асоціація зареєстрованих медичних сестер Онтаріо (RNAO) взяла на себе провідну роль у створенні та розповсюдженні понад п'ятдесяти рекомендацій $з$ найкращої практики з різних питань догляду за пацієнтами, таких як знеболення, допомога в кінці життя та співпраця між медичними сестрами. Згідно 3 даними Асоціації медичних сестер Канади (CNA) [14], рекомендації з найкращої практики базуються на найдостовірніших дослідженнях, таких як систематичні огляди та рандомізовані контрольовані дослідження, але також включають дослідження, «ґрунтовані на експертній думці та консенсусі».

Не кожне медсестринське дослідження може мати значення для конкретного пацієнта, питання, теми чи проблеми. Тому майбутнім науковцям 3 медсестринства потрібно ретельно оцінювати кожну дослідницьку роботу, яку вони розглядають - шукати слабкі місця, невідповідності, упередження та інші проблеми. Практика, заснована на доказах, вимагає вміння виконувати ці оцінки та робити власні висновки щодо інорормації, яка використовується.

види досліджень

Дослідження, що використовуються в медсестринській практиці та ґрунтуються на доказах, можуть бути кількісними, якісними або змішаними. Розуміння того, як можна класифрікувати дослідження медсестер, може допомогти науковцям зрозуміти та інтерпретувати результати власних досліджень [15].

Кількісне дослідження можна охарактеризувати так: для передачі результатів використовуються числа, відсотки та змінні.

При якісних дослідженнях результати набувають орорми думок, сприйняття та досвіду [16].

Виділяють три типи кількісних досліджень:

- описове дослідження, що виражає характеристики або риси певної групи, ситуації чи особистості;

- квазіекспериментальне дослідження - розглядає причинно-наслідкові зв'язки між різними змінними;

- кореляційне дослідження, що розглядає зв'язки між змінними, але не виявляє причинно-наслідкового зв'язку. 
Серед якісних досліджень виділяють п'ять типів $[17,18]$ :

- етнографрія спостерігає або надає аналіз культурних і соціальних звичаїв і практик, а також того, як окремі культури розуміють хвороби і здоров'я;

- обґрунтована теорія - це створення теорій у відповідь на запитання, проблеми та спостереження;

- символічний інтеракціонізм - вивчає особисту взаємодію, моделі спілкування, інтерпретації та реакції. Ці фрактори можуть вплинути на те, як люди змінюють свою практику здоров'я з часом;

- історичне дослідження, яке систематично розглядає тему, культуру чи групу та історію суб'єкта.

- френоменологія, що використовує особистий досвід і розуміння, щоб зробити висновок автора.

Жоден конкретний тип дослідження не обов'язково $€$ кращим за інші, але кожен тип має певні можливості використання та обмеження. Медсестрам - майбутнім науковцям важливо знати різні типи досліджень і як їх використовувати.

3 січня 2021 р. ННІ медсестринства Тернопільського національного медичного університету та університет Макюена (Канада) розпочали новий спільний проект: вивчення курсу «Якісні методи дослідження в медсестринстві».

Розробниками та викладачами цього курсу $є$ Елізабет Берджес-Пінто, доцент фракультету сестринської справи університету МакЮвен (Канада), Оленка Білаш, профресор Університету Альберти

\section{СПИСОК ЛІТЕРАТУРИ}

1. Polit D. F. Nursing research: Generating and assessing evidence for nursing practice / D. F. Polit, C. T. Beck. - 10th ed. Philadelphia, PA: Wolters Kluwer; 2017.

2. Stevens K. The impact of evidence-based practice in nursing and the next big ideas / K. Stevens // OJIN: The Online Journal of Issues in Nursing. - 2013. - Vol. 18, No. 2, Manuscript 4.

3. Improving health related quality of life among rural hypertensive patients through the integrative strategy of health services delivery: a quasi-experimental trial from Chongqing, China / Y. Miao, L. Zhang, V. Sparring [et al.] // Int. J. Equity Health. - 2016. - No. 15 (1). - P. 132.

4. Decreased body mass index in schoolchildren after yearlong information sessions with parents reinforced with web and mobile phone resources: Community trial / J.Vilchis-Gil, M. Klünder-Klünder, X. Duque, S. FloresHuerta // J. Med. Internet Res. - 2016. - No. 18 (6). - P. e174.

5. Designing clinical research / S. B. Hulley, S. R. Cummings, W. S. Browner [et al.]. - 4rd ed. Philadelphia: LWW, 2013. 378 p.

6. Balakas K. Collaborative research partnerships in support of nursing excellence / K. Balakas, T. Bryant, P. Jamerson // Nursing Clinics of North America. - 2011. Vol. 46, No. 1. - P. 123-128.

7. National Academies of Sciences, Engineering, and Medicine 2021. The Future of Nursing 2020-2030: Charting
(Канада) та Лариса Гайдук, керівник Українського центру ресурсів та розвитку університету МакЮвен (Канада).

Слухачами даного курсу є аспіранти та пошукувачі PhD програми з медсестринства, а також викладачі нашого університету. Мета даного курсу полягає у вивченні методології використання якісних методів в науковому дослідженні медсестер. 3окрема, планується на конкретному дослідницькому проекті з медсестринства відпрацювати методи збору та обробки інорормації, залучення слухачів курсу до попереднього тематичного кодування та аналізу даних; інтерпретація висновків.

\section{висновки}

Медсестринські дослідження є життєво важливими для практики профресійного медсестринства, і науковці по всьому світу, а тепер і в Україні усвідомлюють, що догляд і дослідження можна поєднувати і що оптимальний догляд залежить від останніх результатів досліджень.

Для медичних сестер важлива також практика, заснована на доказах. Медсестри повинні розуміти, оцінювати та використовувати наукові дослідження у своїй практиці.

В аспірантурі з медсестринства ТНМУ навчають цим навичкам і готують науковців, здатних ретельно оцінювати кожну дослідницьку роботу, яку вони розглядають - шукати слабкі місця, невідповідності, упередження та інші проблеми.

a Path to Achieve Health Equity. Washington, DC: The National Academies Press. DOI: 10.17226/25982.

8. Kelly L. A. Nurse outcomes in Magnet ${ }^{\circledR}$ and nonMagnet hospitals / L. A. Kelly, M. D. McHugh, L. H. Aiken // J. Nurs. Adm. - 2011. - Vol. 41 (10). - P. 428-433

9. An academic-health service partnership in nursing: lessons from the field / B. B. Granger, J. Prvu-Bettger, J. Aucoin [et al.] // Journal of Nursing Scholarship. - 2012. - Vol. 44, No. 1. - P. 71-79.

10. Akerjordet K. Clinical nurses' attitutdes toward research, management and organizational resources in a university hospital: part 1 / K. Akerjordet, K. Lode, E. Severinsson // Journal of Nursing Management. - 2012. - Vol. 20. - P. 814-823.

11. Development of a regional nursing research partnership for academic and practice collaborations / L. Heather, Tubbs-Cooley, S. Donna[etal.]//Hindawi Publishing Corporation Nursing Research and Practice. - Volume 2013. Article ID 473864. - DOI: 10.1155/2013/473864 Research Article.

12. Корж О. О. Актуальні проблеми медичних досліджень / О. О. Корж, Б. І. Сіменач // Наука та наукознавство. - 2005. - № 3. - С. 59-65.

13. Котепчук В. А. Формування науково-педагогічної еліти 3 медсестринства в медичних навчальних закладах / В. А. Котепчук // Вища освіта в медсестринства:

\section{$4(10), 2021$}


проблеми і перспективи. - Житомир : Полісся, 2011. 392 c.

14. Проблеми і перспективи розвитку медсестринства у світі і в Україні (історичний аспект і сучасність) / В. Й. Шатило, О. В. Горай, С. В. Гордійчук [та ін.] // Вища освіта в медсестринства: проблеми і перспективи. - Житомир: Полісся, 2011. - 392 с.

15. Canadian Nurses Association. Evidence-informed decision making and nursing practice. - 2010. - Access mode : http://www.nanb.nb.ca/PDF/CNA-Evidence Informed_Decision_Making_and_Nursing_Practice_E.pdf

16. Адаменко М. І. Основи наукових досліджень /

\section{REFERENCES}

1. Polit DF, Beck CT. Nursing kesearch: Generating and assessing evidence for nursing practice. 10th ed. Philadelphia, PA: Wolters Kluwer; 2017.

2. Stevens K. The impact of evidence-based practice in nursing and the next big ideas. OJIN: The Online Journal of Issues in Nursing. 2013;18(2). Manuscript 4.

3. Miao Y, Zhang L, Sparring V, Sandeep S, Tang W, Sun $X$ et al. Improving health related quality of life among rural hypertensive patients through the integrative strategy of health services delivery: a quasi-experimental trial from Chongqing, China. Int J Equity Health. 2016;15(1): 132.

4. Vilchis-Gil $J$, Klünder-Klünder $M$, Duque $X$, FloresHuerta $S$. Decreased body mass index in schoolchildren after yearlong information sessions with parents reinforced with web and mobile phone resources: Community trial. J Med Internet Res. 2016;18(6): e174.

5. Hulley SB, Cummings SR, Browner WS, Grady DG, Newman TB. Designing clinical research. 4rd ed. Philadelphia: LWW; 2013.

6. Balakas K, Bryant T, Jamerson P. Collaborative research partnerships in support of nursing excellence. Nursing Clinics of North America. 2011;46(1): 123-8.

7. National Academies of Sciences, Engineering, and Medicine 2021. The Future of Nursing 2020-2030: Charting a Path to Achieve Health Equity. Washington, DC: The National Academies Press. Available from: https://doi. org/10.17226/25982.

8. Kelly LA, McHugh MD, Aiken LH. Nurse outcomes in Magnet ${ }^{\circledR}$ and non-Magnet hospitals. J Nurs Adm. 2011;41(10): 428-33.

9. Granger BB, Prvu-Bettger J, Aucoin J. An academichealth service partnership in nursing: lessons from the field. Journal of Nursing Scholarship. 2012;44(1): 71-9.

10. Akerjordet K, Lode K, Severinsson E. Clinical nurses' attitutdes toward research, management and organizational
М. І. Адаменко, М. В. Бейлін. - Х. : ХНУ імені В. Н. Каразіна, 2014. - 188 c.

17. Standards for reporting qualitative research: $A$ synthesis of recommendations / B. C. O'Brien, I. B. Harris, T. J. Beckman [et al.] // Acad. Med. - 2014. - Vol. 89 (9). P. $1245-1251$.

18. Immy Holloway and Kathleen Galvin. Qualitative Research in Nursing and Healthcare 4th Edition. - 2018.

19. "Blind leading the blind": Qualitative evaluation of unanticipated difficulties during nurse testing of a hospital health information system / K. Bail, E. Merrick, B. Redley [et al.] // Collegian. - 2019. - Vol. 27 (1). - P. 82-88.

resources in a university hospital: part 1 . Journal of Nursing Management. 2012;20: 814-23.

11. Heather L Tubbs-Cooley, Donna S Martsolf, Rita H Pickler, Caroline F Morrison, Cassie E Wardlaw. Research article development of a regional nursing research partnership for academic and practice collaborations Hindawi Publishing Corporation ursing Research and Practice. 2013. Article ID 473864. DOI:10.1155/2013/473864.

12. Korzh OO, Simenach BI. [Current problems of medical studies]. Nauka ta naukoznavstvo, 2005;3: 59-65. Ukrainian.

13. Kotepchuuk VA. [Formation of scientific and pedagogical elite in nursing in medical schools]. Vushcha osvita v medsestr: probl i perspekt. Zhytomyr: Plissia; 2011. Ukrainian.

14. Shatylo VI, Ed. [Problems and prospects of nursing development in the world and in Ukraine (historical aspect and present)].Vyshcha osvita $v$ medsestrynstva: problemy $\mathrm{i}$ perspektyvy. 2012; Zhytomyrю Ukrainian.

15. Canadian Nurses Association. Evidence-informed decision making and nursing practice; 2010. Available from: http://www.nanb.nb.ca/PDF/CNA-Evidence_Informed Decision_Making_and_Nursing_Practice_E.pdf

16. Adamenko MI, Beilin MV. Bases of scientific studies. [Основи наукових досліджень] Kharkiv: KhNU imeni V. N. Karazina; 2014. Ukrainian.

17. O'Brien BC, HarrisIB, BeckmanTJ, ReedDA, CookDA. Standards for reporting qualitative research: A synthesis of recommendations. Acad Med. 2014;89(9): 1245-51.

18. Immy Holloway, Kathleen Galvin. Qualitative research in Nursing and Healthcare 4th Edition; 2018.

19. Bail K, Merrick E, Redley B, Gibson J, Davey R, Currie M. "Blind leading the blind": Qualitative evaluation of unanticipated difficulties during nurse testing of a hospital health information system. Collegian. 2019;27(1): 82-88. 